\title{
The Eu Crossing Arctic Frontiers: The Barents Euro-Arctic Council, Northern Dimension, and EU-West Nordic Relations
}

\author{
Alyson J.K. Bailes and Kristmundur P. Ólafsson
}

1

Introduction and Background

When the Arctic Council's Ministerial meeting of April 2015 decided to further defer a decision on the European Union's (EU) application for observership, ${ }^{1}$ this represented at worst a symbolic and diplomatic setback. In reality, the EU was extending its footprint into the Arctic zone well before the current public excitement over the region began. By 1995 it had three members-Denmark, Finland and Sweden-who were also founders of the Arctic Environmental Protection Strategy (AEPS), the leading platform for Arctic-wide inter-governmental cooperation on which the Arctic Council (AC) was founded in $1996 .^{2}$ The fact that Denmark's autonomous territories of the Faroe Islands and Greenland opted out of their motherland's EU membership was balanced by the entry of Norway and Iceland into the European Economic Area (EEA) and Schengen Treaty system in the 1990s. The remaining State members of the ACCanada, the Russian Federation and the United States - are all long-standing partners of the EU and have concluded many cooperation agreements that include their Far Northern regions. In these and other ways, including substantial business and trade links, and sectoral policies e.g. on shipping, fishing and climate change, the $\mathrm{EU}$ helps to shape both the network of political and economic relationships and the regulatory landscape characterizing the

* Alyson J.K. Bailes, Adjunct Professor, University of Iceland, Iceland. Alyson Bailes sadly passed away on 29 April 2016.

** Kristmundur P. Ólafsson, Senior Advisor, Icelandic Centre for Research, Iceland.

1 See para. 51, Iqaluit Declaration (communiqué of the Arctic Council Ministerial meeting, 24 April 2015) <https://www.utanrikisraduneyti.is/media/nordurslodir/ACMMCAo9_ Iqaluit_2015_Iqaluit_Ministerial_Declaration_2015_signed.pdf $\geq$ accessed 17 July 2016.

2 See <http://www.arctic-council.org/index.php/en/about-us/arctic-council/20-year-anniversary> accessed 17 July 2016. 
Euro-Atlantic segment of the Arctic. ${ }^{3}$ It has also, of course, engaged in an open process of policy-forming on Arctic issues since 2008 and recently published an integrated EU policy for the Arctic outlining the Unions' ambition to play a key role in the Arctic region. ${ }^{4}$

There remains one mode of $\mathrm{EU}$ involvement that has been little noticed in policy discussions or academic study, but which arguably owes much of its value precisely to its low profile and non-contentious nature. Like most other parts of the greater European space, the High North is crisscrossed by what will here be called sub-regiona ${ }^{5}$ groupings of neighbour countries linked by land and/or a common sea space. The oldest and smallest, Nordic Cooperation, is limited to the five Nordic States with their special-status territories. ${ }^{6}$ One of Europe's most successful post-Cold War creations, the Barents EuroArctic Council (BEAC) launched in 1993, has however counted the European Commission (now the European Union) as a full member from the start. ${ }^{7}$ In 1999, moreover, the EU created its own Northern neighbourhood framework in the form of the Northern Dimension (ND), ${ }^{8}$ which continues today-following a make-over in 2006-as a four-way grouping of Iceland, Norway, Russia and the EU with its Member States. To complete the picture, ${ }^{9}$ the West Nordic Council (WNC $)^{10}$ has been growing in prominence since it adopted that name in 1997 (formerly the West Nordic Parliamentarian Council). It consists of the three non-EU members Iceland, Greenland and the Faroes and has no formal link to Brussels, but each of its member nations is increasingly engaged with the EU on issues fully relevant to the Arctic.

3 These connections are discussed at greater length in Alyson J.K. Bailes, The Arctic as European Periphery, International Security Network 2015 <https://www.stratfor.com/the -hub/arctic-european-periphery> accessed 17 July 2016.

The relevant documents including contributions by the European Parliament, European Commission papers of 2008 and 2012, and Council conclusions of 2009 and 2014, are available at the EEAS webpage <http://eeas.europa.eu/arctic_region/> accessed 17 July 2016. The rationale for the term is that the UN considers Europe as a whole to be a 'region'. Similar localized institutions are found within other large 'regions', notably in Africa and the Americas.

6 <http://www.norden.org > accessed 17 July 2016.

$7 \quad<$ http://www.beac.st/en/About/Members> accessed 17 July 2016.

$8<$ <ttp://eeas.europa.eu/north_dim/index_en.htm> accessed 17 July 2016.

9 The Nordics, Russia and the EU also take part in the Council of Baltic Sea States (cBss, <http://www.cbss.org> accessed on 17 July 2016) together with Poland and Germany, but since it has (so far) no Arctic connections or activities the свss is not covered in this paper. $<$ http://www.vestnordisk.is/english/> accessed 17 July 2016. 
The purpose of this chapter is to introduce the BEAC, ND and WNC in greater detail and to consider what place they hold in the bigger picture of EU-Arctic relations. What are their capabilities, prospects, and limitations? Does the EU itself recognize their importance within its potential Arctic tool-box? How effectively has it been using them in pursuit of general influence and standing, and concrete impacts corresponding to its policy goals? Is anything changing and could anything be improved in this respect?

To set the analytical scene, this introduction concludes with some general remarks on sub-regional institutions, their role in international governance, and how the EU has interacted with them historically. The next three sections-II, III and IV-apply the paper's research questions in turn to the BEAC, the ND, and the WNC with its individual members. Section $\mathrm{V}$ presents the conclusions.

\subsection{Sub-regional Institutions}

Sub-regional groupings in Europe and elsewhere vary greatly in size and membership. Their frequently overlapping boundaries reveal how often they reflect 'constructed', rather than natural spaces,"11 and they tend to cluster in some areas more than others-for instance, in Northern and Central rather than Western and South-western Europe. The smallest groups, such as Benelux, Nordic Cooperation, and the Visegrad cooperation of the Czech Republic, Hungary, Poland and Slovakia, ${ }^{12}$ are easy to explain as sets of like-minded neighbours with shared historical/cultural features, who find advantage in pooling efforts and forming common fronts to deal with larger partners. One co-author of this paper has in another context called them 'brotherhood' groupings. ${ }^{13}$

In the late 1980s and 1990s, Europe generated several larger groups that could more neutrally be called 'neighbourhood' ones, with members who were not necessarily homogenous in nature or interests, but held the management of a given physical space in common. These were explicitly designed to cross east-west dividing lines and help avoid, or at least limit the impact of new dividing lines with countries remaining outside the EU and NATO. ${ }^{14}$ The regional

11 Iver B. Neumann, Uses Of The Other: "The East" in European Identity Formation, Minneapolis: University of Minnesota Press, 1998.

12 <http://www.visegradgroup.eu/about> accessed 17 July 2016.

13 Alyson J.K. Bailes, 'Understanding the Arctic Council: A “Sub-regional” Perspective' (2013) 15(2) JMSS $31<$ http://jmss.org/jmss/index.php/jmss/article/view/527/513> accessed 27 July 2016.

14 Andrew Cottey, 'Sub-regional Cooperation in Europe: An Assessment' (2009) 3 Bruges Regional Integration and Global Governance Papers <http://cris.unu.edu/sites/cris.unu .edu/files/BRIGG_3-2009_revised_version.pdf> accessed 17 July 2016. 
cooperation frameworks were a way to work for understanding and stabilization through the new contacts involved as much as through their concrete actions. In the fluid environment created by the collapse of Communism in Europe they also often sought to stimulate local democracy and empower the oft-neglected peripheries of nations through profitable cross-border cooperation. ${ }^{15}$ Russia was drawn into them in the South-east (Black Sea groupings), as well as in the Northern instances already mentioned.

The typical weaknesses of such groups are dictated above all by the diversity of their members. Differences of size and wealth, as well as of strategic stance and political culture, tend to rule out common binding legislation or systematic harmonization of standards. A fortiori such groups cannot become defence unions, and they more typically operate by sidelining difficult security issues and bilateral disputes (a process conceptually recognized as de-securitization). ${ }^{16}$ In institutional typology they are easily viewed as 'weak' for these reasons, but also because of the lightness of their governance structures, without large (or any) secretariats, with minimal budgets or project management capacities, and with typically low political and public profiles. ${ }^{17}$ Some groupings, notably on the Eastward periphery of Europe and in Central Asia, can fairly be described as paper institutions that offer little except a chance for their members to talk discreetly and for countries to show off when hosting meetings.

The better functioning groups, however-and the BEAC is often cited in this category - can be remarkably productive using 'softer' or 'messy' governance methods such as politically binding declarations, coordinated spending programmes, externally funded infrastructure designs, exercises and training, and networking activities. ${ }^{18}$ These measures can bring tangible benefits in areas of non-military security such as border control (with anti-crime, antismuggling and anti-trafficking elements), environmental safety including

15 Alyson J.K. Bailes 'The Role of Subregional Cooperation in Post-Cold War Europe: Integration, Security, Democracy' in Andrew Cottey (ed.) Sub-regional Cooperation in the New Europe, (London, 1999). This effect was often cited in the 1990s in relation to the BEAC, when Russian Foreign Minister Kozyrev was also the MP for Murmansk and encouraged initiatives by the local authorities.

16 De-securitization is the opposite of securitization and means declining to recognize something as a security issue even if it has the obvious characteristics of a threat. Actors may do this if they are powerless to respond, but also in order to establish communication and cooperation with prima facie opponents. For a classic statement of the theory see Barry Buzan, Jaap de Wilde and Ole Wæver, Security: A New Framework for Analysis. (Boulder, Colorado: Lynne Rienner publishers 1998).

17 Dai, Xinyuan. International Institutions and National Policies (New York: Cambridge University Press, 2007).

18 For a systematic listing of such strengths and weaknesses see Bailes, n. 13 above. 
nuclear clean-up, coordinated infrastructure planning inter alia for energy supply, disease control, and response to civil emergencies (accidents and natural disasters). Further, the primary sub-regional institution may gain 'depth' by sponsoring sub-state networks of neighbouring provincial authorities, sectoral experts and researchers, and non-State analogues (banks, hospitals, universities, youth groups etc). ${ }^{19}$

The interaction of sub-regional groupings with more powerful regional ones is by no means free of contradictions. In the early 1990s, some applicants for North Atlantic Treaty Organization (NATO) and EU membership mistrusted Western support for groups like the Council of the Baltic Sea States (CBSs) and Central European Initiative because they feared they might get trapped permanently in such 'waiting rooms': condemned to a second-best that denied them true strategic protection or full free market access. The fact that the Visegrad cooperation (and its economic counterpart, CEFTA) manifestly helped the Czech Republic, Hungary and Poland to get into NATo faster had eased such concerns by the mid-199os and made it possible to see the groups as useful training schools for the integration-minded..$^{20}$ NATO and the EU for their part, however, were nervous of candidates 'ganging up' and responded by strengthening their emphasis on individual entry negotiations based on individual merits. In retrospect, they probably failed to grasp how important the sub-regional groups were in sublimating historical disputes that would otherwise have disturbed candidates' progress, or even the peace, in more parts of Europe than just the Western Balkans.

The EU had a more concrete reason for concern because the adoption of economic and functional standards at neighbourhood level might have preempted and diverged from its own regulatory requirements, thus making adaptation unnecessarily hard for countries once started on the accession track. It was, in fact, in the North European cases-CBss and BEAC - that Brussels first chose to address this problem proactively by entering the groups concerned and seeking to lead on issues related to Community competence. As it turned out, countries bent on accession concentrated on EU models from the start in frameworks like the PHARE programme; ${ }^{21}$ and their efforts to find ways of

19 See Bailes, n. 15 above.

20 See Cottey, n. 14 above.

21 The PHARE programme was a specific EC programme as was the main funding instrument used to prepare Central and Eastern European countries for accession. Implementation of PHARE was largely de-centralised to the recipient countries and among the sub-programmes provided were cross-border programmes that were intended to support cooperation between PHARE countries and the adjoining border regions of the EU. The PHARE was the predecessor of the 'Instrument for Pre-Accession Assistance 
TABLE 1 Comparison of the three sub-regional structures, key facts

\begin{tabular}{|c|c|c|c|}
\hline Organization & BEAC & ND & wNC \\
\hline Website & www.beac.st & $\begin{array}{l}\text { http://www.eeas. } \\
\text { europa.eu/north_dim/ }\end{array}$ & $\begin{array}{l}\text { http://www. } \\
\text { vestnordisk.is/ }\end{array}$ \\
\hline Year founded & 1993 & 1999 & $1997^{*}$ \\
\hline Secretariat? & Kirkenes & $\begin{array}{l}\text { (Varies for each } \\
\text { programme) }\end{array}$ & Reykjavik \\
\hline Members & $\begin{array}{l}\text { Denmark } \\
\text { Finland }^{* *} \\
\text { Iceland } \\
\text { Norway } \\
\text { Sweden } \\
\text { Russian Fedn. } \\
\text { European } \\
\text { Commission }\end{array}$ & $\begin{array}{l}\text { Denmark as EU State } \\
\text { Finland as EU State } \\
\text { Iceland*** } \\
\text { Norway } \\
\text { Sweden as EU State } \\
\text { Russian Federation } \\
\text { European Union } \\
\text { (+other EU member } \\
\text { States in national role) }\end{array}$ & $\begin{array}{l}\text { Greenland } \\
\text { Faroe Islands } \\
\text { Iceland } \\
* * * *\end{array}$ \\
\hline Observers & $\begin{array}{l}\text { Canada, France, } \\
\text { Germany, Italy, } \\
\text { Japan, Netherlands, } \\
\text { Poland, U K, Us }\end{array}$ & Canada, us & \\
\hline
\end{tabular}

\footnotetext{
* Existed from 1985 as West Nordic Parliamentarian Council of Cooperation

** Those in italics can hold the rotating chairmanship and participate in regional-level cooperation

*** Those in bold are the formal signatories and 'owners' of the forum

**** The Western coastal provinces of Norway are included for some cultural/social purposes
}

cooperating — nonetheless — with non-candidates like Russia often provided useful groundwork for the EU's own neighbourhood strategies..$^{22}$ This link was

(IPA)' used for the current enlargement countries. European Parliament, Briefing: The PHARE Programme and the enlargement of the European Union, No 33 /1998. <http:// www.europarl.europa.eu/enlargement/briefings/33a1_en.htm> accessed on 22 July 2016.

22 Based on interviews conducted by Alyson J.K. Bailes with EU Commission officials conducted in May 2015. 
manifest when the EU in 2009 adopted its first Baltic Sea regional strategy, ${ }^{23}$ taking the work of the CBSS as one of its main inspirations and foundations. ${ }^{24}$ In this regard, as well as through the practical solutions they sought for geographically limited and specialized challenges, the more successful regional groups could be seen both historically and today as relating to Brussels in a mode of rational subsidiarity. ${ }^{25}$ This hypothesis can be explored in more detail through the case-studies of sections 2 and 3 .

\section{2 The Barents Euro-Arctic Council ${ }^{26}$}

The Barents Euro-Arctic Council was founded on a Norwegian initiative in 1993, with the five Nordic countries, Russia and the European Commission as members and several other NATO members as observers (see Table One). Its focus area is the Northernmost segment of Scandinavia (historically known as 'Nordkalotten') which includes the Norwegian-Russian frontier and the northernmost provinces of Sweden and Finland. From the start, BEAC has had a two-tier structure, with the inter-governmental Council complemented by a Barents Regional Council (в RС $)^{27}$ where representatives of the provincial authorities (and of the Sami community) meet to discuss cross-border issues including the use of project funding.

The Council was strengthened in 2008 by the establishment of a dedicated secretariat in Kirkenes; it is however still relatively small, having just three employees with very limited financial means. ${ }^{28}$ Much still depends on the energy

23 European Commission, Communication: European Union Strategy for the Baltic Sea Region, Brussels, 10.6.2009 Сом(2009) 10 June 2009. <http://ec.europa.eu/regional_policy/ sources/docoffic/official/communic/baltic/com_baltic_en.pdf> accessed on 17 July 2016.

24 See Bailey, n. 22 above.

25 As used in the EU, subsidiarity is the principle that tasks should be handled at the lowest (in this context, most local) feasible level.

26 This section draws largely on Ingmar Oldberg, The role of Russia in Regional Councils: A comparative study of neighbourhood cooperation in the Baltic Sea and Barents Euro-Arctic regions, Centre for Arctic Policy Studies (Reykjavik, 2014) <http://ams.hi.is/wp-content/ uploads/2014/08/The-role-of-Russia_Online.pdf > accessed on 17 July 2016; and on Alyson J.K. Bailes and Kristmundur P. Ólafsson, 'Northern Europe and the Arctic Agenda: Roles of Nordic and other Sub-regional Organizations' (2013) 5 The Yearbook of Polar Law 45-73.

27 The Barents Regional Council (BRC) comprises 13 regions/provinces in the north of Finland, Sweden, Norway and Russia.

28 It is funded by the 'inner four' BEAC members only. For an insight into its work see $<\mathrm{http} / /$ www.beac.st/newsletter/Newsletter-1-2015> accessed 17 July 2016. 
and priorities of the Chairmanship, which rotates annually between the four contiguous countries (only): Finland, Norway, Sweden and the Russian Federation. Added 'depth' is given to the structure through 16 working groups serving either or both of the Councils-five of them report to both the regional and governmental levels. There are several multi-functional programmes such as the Action Plan on Climate Change in the Barents Region ${ }^{29}$ and the Cooperation Programme on health and social issues (2012-2015). ${ }^{30}$ The scope and importance of this regional cooperation has increased steadily as economic activity and the utilization of natural resources in the region has increased.

Original Norwegian motives for launching the initiative were both Russiarelated and EU-related. ${ }^{31}$ In the early 1990s when Russia's internal development was uncertain, there were fears of a collapse of public services in the country's industrialized and militarized North-west that could trigger a surge of Westward migration. Meanwhile, Russia's troop withdrawals from Central Europe made its remaining capacities in the Kola peninsula loom proportionally larger as a cause of concern for Norway in particular. Against this background BEAC was designed not only to ease tension and to build understanding and shared interests for general stabilization purposes, but to find acceptable ways of aiding the population in the Russian Western Arctic so that pressures for migration were reduced. The prospect of EU funding was attractive in this context, but the Commission's participation had two larger merits in Norwegian planners' eyes. First, it signalled multilateral backing for the small Nordic countries as they sat down to work with a much larger and still potentially threatening neighbour. Secondly, in the run-up to Norway's EU membership referendum, it was hoped that the distinctly Euro-sceptic North Norwegian population might be won over by using EU money for local projects. This last hope was proved vain by the 'No' vote on Norwegian accession in 1995, but the other rationales for EU participation still hold good and seem to be well appreciated by other actors.

The BEAC's main fields of activity have been: local economic development, including the fostering of trade and investments; transport, visa matters and

29 Barentsinfo, Workshop on Development of a Draft Action Plan on Climate Change for the Barents Region <http://www.barentsinfo.fi/beac/docs/ClimateChangeActionPlanWork shopMarch2012Minutes.pdf> accessed 19 July 2016.

30 Barentsinfo, 4th Co-operation Programme on Health and Related Social Issues in the Barents Euro-Arctic Region 2012-2015 <http://www.barentsinfo.fi/beac/docs/JWGHS_ Cooperation_Programme_2012_2015_ENG.pdf > accessed 19 July 2016.

31 This paragraph is based on one of the author's own (Alyson J.K. Bailes) observations as a diplomat at Oslo in 1991-4. 
cooperative border management (to ease movement for the 'good' and keep out the 'bad'); energy cooperation; environment protection - especially pollution clean-up on the Russian side - and climate policy; health issues; support for indigenous peoples; democratic development, culture, education and science; and cooperation in civil emergency management. On the face of it, successful activities in all these fields can claim a 'subsidiarity' role: they address and are adapted to the region's very distinct local needs - and can be kept close to the people through the $\mathrm{BRC}$-without risk of challenging or duplicating the Eu's regulatory framework, which all five Nordics adhere to in relevant fields under the EEA. Locally generated finance, which in practice has mostly come from Norway, eases the burden on collective European funds. From the EU viewpoint, the BEAC (like the ND, see below) is particularly helpful in addressing important issues at regional level and which can have a substantial impact on local communities facing new challenges and opportunities. While the EU is channeling funds to the region under several of the EU's regional schemes ${ }^{32}$ it has recognized the need to both increase the funding level and make it more coordinated and effective. ${ }^{33}$ BEAC provides a platform that the EU could potentially look towards in order to achieve goals that fit a wider regional strategy at the same time the Union could count on other Council members' buy-in.

Secondly, the BEAC's effectiveness in stabilizing relations with Russia eases tensions in a delicate border zone that might otherwise have demanded a higher pitch of attention and engagement from both the EU and NATO. While in the nature of things non-quantifiable, this effect seems to be real and has been credited, ${ }^{34}$ notably, with paving the way for the Russian-Norwegian Treaty on Maritime Delimitation and Cooperation in the Barents Sea and the Arctic Ocean, signed in 2010. ${ }^{35}$ Further, the BEAC's low profile and 'de-securitized'

These include $€_{24}$ million for the 'Kolarctic' border region, $€_{21}$ for Karelia, $€_{34.4}$ million for 'Botnia-Atlantica' (northernmost provinces of Norway, Sweden and Finland), the 'Interreg IVA North' and 'Northern Periphery and Arctic' programmes, and funds applicable in the North from the Baltic Sea basin programme.

33 Joint Communication of the European Commission and High Representative of the European Union for Foreign Affairs and Security Policy of 27 April 2016 on An Integrated European Union Policy for the Arctic, JOIN (2016) 21.

34 This can be seen at the joint declaration made after the joint Barents Summit in Kirkenes, Norway 2013 held at ministerial level. <http://www.barentsinfo.fi/beac/docs/Barents_ Summit_Declaration_2013.pdf > accessed 19 July 2016. 
nature have allowed it to continue functioning quite normally through periods of Russia-West strain (not least in 2014-15), thus inter alia providing a channel for informal messages and explanations between the two sides. This facility may be helpful not least for the Commission in cases where the $\mathrm{EU}$ is embroiled in the given dispute.

Last and not least as an aspect of the BEAC's value, it is indisputably-and more clearly so than the ND-an organ of Arctic management, offering the $\mathrm{EU}$ a direct corridor of involvement into the latter. The Nordkalotten region lies largely above the Arctic Circle, and (as just noted) is a local test-place for the Russia-West relationship that provides the main diplomatic challenge in Arctic cooperation generally. Its material challenges are a microcosm of those affecting the whole populated Arctic, especially in terms of climate change; the contradictions and choices in economic development; the strains on the human population; and the daunting risks of civil emergencies (accidents and natural disasters) for which response capacities are all too slight. Its waters constitute the Western end of the Northern Sea Route (NSR) over Russia which has so far witnessed the main, though not consistent, growth in trans-Arctic shipping. ${ }^{36}$ On land, the Barents region includes some of the largest population centres above the Arctic Circle: Russia's Murmansk and Arkhangelsk both have around 300,000 inhabitants, offering a useful reminder that not only the indigenous peoples need help in navigating a changed Arctic future. In governance terms, the BAEC and Arctic Council may learn from each other about viable solutions in building consensus: the latter's 2011 agreement on Search and Rescue (S\&R) cooperation was preceded by the signing in 2008 of an equivalent agreement among the BEAC's six states members. ${ }^{37}$

15 September 2010, entered into force 7 July 2011). <http://www.un.org/depts/los/ LEGISLATIONANDTREATIES/PDFFILES/TREATIES/NOR-RUS2010.PDF > accessed 27 July 2016. This Treaty resolved long-standing disputes on the two States' maritime demarcation line, with positive knock-on effects also for fisheries and shipping cooperation. While the BEAC has no direct competence in the matter, relationships built through the Barents cooperation are credited by both sides with having eased the negotiations.

36 While BEAC's agenda has traditionally been land-focused, the Ministerial session of October 2013 issued a communiqué including (para. 18) reference to the importance of the NSR and commending the International Maritime Organisation's proposed safety code for polar shipping. <http://www.barentsinfo.fi/beac/docs/BEAC_14_Session_ Tromso_29_October_2013_Communique_final_ENG.pdf> accessed 19 July 2016.

37 Agreement Between The Governments In The Barents Euro-Arctic Region On Cooperation Within The Field Of Emergency Prevention, Preparedness And Response (Adopted 11 December 2008, entered into force 17 May 2012). <https://www.barentsinfo.fi/beac/ 
All the Nordic states as well as the EU have noted the BEAC's relevance and value in their national Arctic strategy documents, ${ }^{38}$ it is clear that this EU recognition goes beyond mere words: the BEAC is consciously used-at least by the EU's External Action Service (and the EU member states who participate) - as a practical, low-key and low-risk channel for consolidating the Union's place and the impact of its funds and policies in the Euro-Arctic zone. The institutional set-up lends itself to this notably through the EEAs's attendance at meetings of the BEAC's Committee of Senior Officials (CSO) which both oversees lower-level activities, and prepares Ministerial decisions. Like the BEAC itself, it is a discreet mechanism for European influence that gains most of its value exactly from being so little known or scrutinized.

\section{Northern Dimension}

First established as an EU policy initiative under the Finnish Presidency in 1999, the Northern Dimension has since 2006 been renewed as a common policy framework, ${ }^{39}$ where the EU as an institution, Russia, Norway and Iceland participate on an equal footing and co-financing is the general rule. The revamping of the organization in 2006 addressed earlier complaints ${ }^{40}$ that it was EU-dominated and over-focused on bilateral interests-especially, the needs of the Finnish-Russian border; it seems to have succeeded in creating a broader and stronger sense of co-ownership, as well as attracting more Russian funds. ${ }^{41}$

docs/Agreement_Emergency_Prevention_Preparedness_and_Response_English.pdf> accessed 27 July 2016.

38 Such references are found in all five Nordic nations' Arctic strategy documents, and in those of Russia and the European Commission. The EU mentions the BEAC a couple of times in its new Integrated policy for the Arctic, JOIN (2016) 21.

This was done at the Helsinki Summit in November 2006 with the adoption of the Northern Dimension Policy Framework Document <http://eeas.europa.eu/north_dim/ docs/frame_pol_1106_en.pdf> accessed on 19 July 2016 and the Political Declaration on the Northern Dimension Policy <http://eeas.europa.eu/north_dim/docs/pol_dec_1106_ en.pdf > accessed 19 July 2016.

40 Haukkala, Hiski, The EU-Russia Strategic Partnership: The Limits of Post-Sovereignty in International Relations (Routledge, 2010) 159-165.

41 Russian Foreign Minister Sergey Lavrov, (Speech delivered at a meeting with Association of European Businesses in the Russian Federation, Moscow, 14 October 2014). <http:// aebrus.ru/upload/iblock/b7f/15_10_2014-lavrov_s-briefing-with-aeb-members-eng.pdf> accessed 28 July 2016. Russian Foreign Minister Lavrov is quoted as saying (of the 2006 re-negotiation): 'Talks were launched, the text was clarified and a concept coordinated, 
The parties' common priorities for the future were defined in the 2006 documents as to promote dialogue and concrete cooperation; strengthen stability, well-being and intensified economic cooperation; and promote economic integration, competitiveness and sustainable development in Northern Europe.

While providing a forum for general political dialogue between the partners, the ND primarily operates through the design and funding of cooperative projects, handled through the four sectoral ND partnerships and other ND structures. ${ }^{42}$ These are the Northern Dimension Environmental Partnership (NDEP), the Northern Dimension Partnership in Public Health and Social Well-being (NDPHS), the Northern Dimension Partnership on Transport and Logistics (NDPTL) and the Northern Dimension Partnership on Culture (NDPC). Specific policy goals are discussed in each partnership group to guide the related project spending. This cooperation is supported ${ }^{43}$ in depth by a network of participants, observer states, International Financial Institutions, ${ }^{44}$ EU Member States, universities and research centers. The result might be seen as a kind of hybrid between a technical investment scheme and a regional 'partnership' in the sense used elsewhere by Brussels; but it escapes some of the quandaries of the latter (for example, in the Eastern Partnership) by

which was jointly conceived by the European Union, Russia, Norway and Iceland. This is the main secret of the Northern Dimension's success. Unlike the Eu's Black Sea and Baltic strategies, this project continues to function on the basis of consensus for charting generally acceptable approaches'.

The secretariat of the NDPHS is co-located with the свss, that of the NDPC with the NCM secretariat in Copenhagen, and that of the NDPTL with the European Investment Bank. There are also - at non-state level—a Northern Dimension Institute, a Northern Dimension Business Council and a Northern Dimension Parliamentary Forum.

43 Most of the supporting actors are mentioned in the Northern Dimension Policy Framework Document, see note 39 above. This excludes the Northern Dimension Institute which prepares Northern Dimension-related studies and reports, and coordinates the collection of funding for research projects. A good example of the support international financial institutions bring to the partnerships is the NDEP support fund, which is managed by the European Bank for Recronstruction and Development (EBRD). The Fund is intended to catalyse environmental investments by mobilising grant co-financing for leveraging loans from the IFIs, this is intended to have a multiplying effect on environmental investment in the area as they make possible larger IFI loans that finance the major share of the investments. Observer States are cooperation partners in some of the action undertaken an have the ability to support initiatives on an ad-hoc basis.

44 The main International Financial Institutions involved are the European Bank for Reconstruction and Development (EBRD), the European Investment Bank (EIB), the Nordic Investment Bank (NIB) and the Nordic Environment Finance Corporation (NEFCO). 
Governmental level

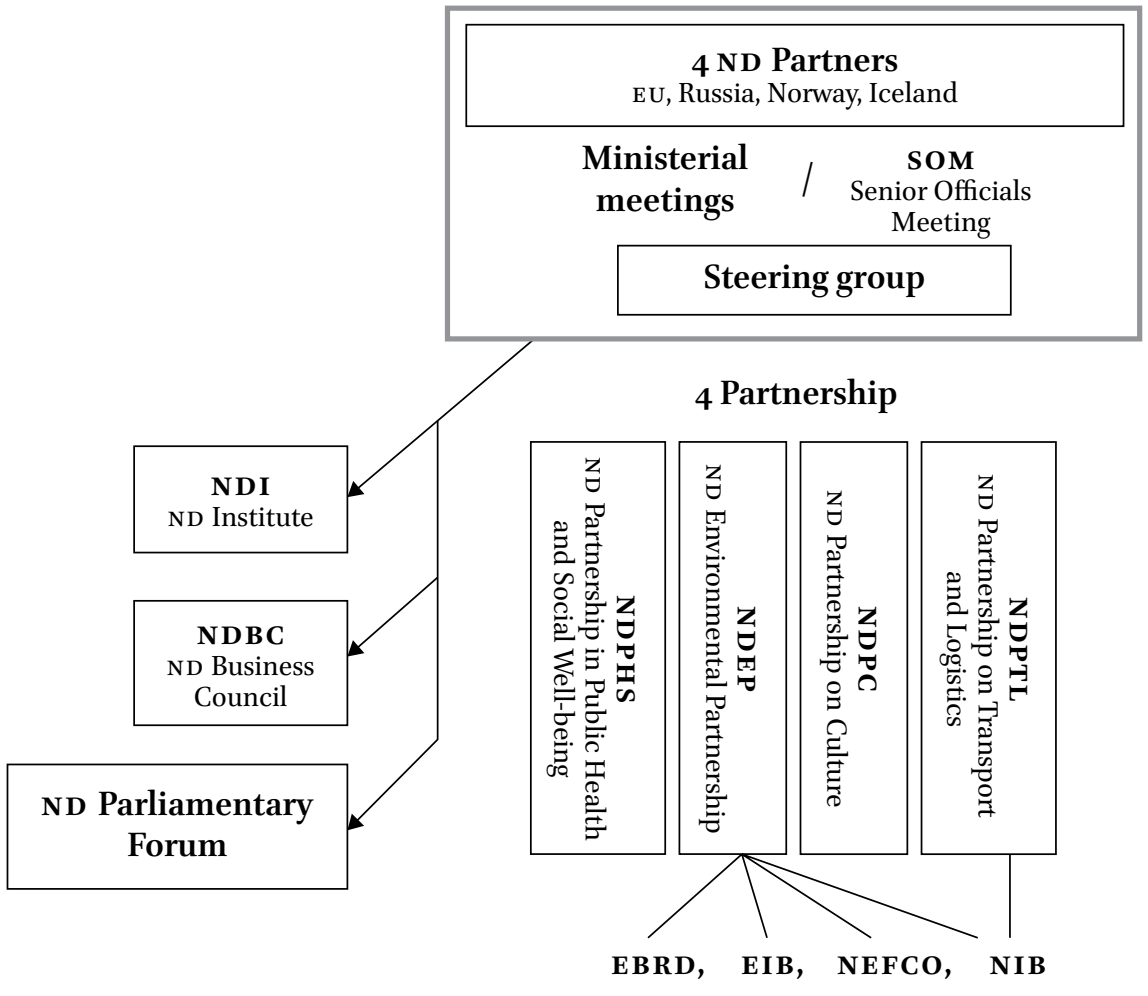

International Financial Institutions

FIGURE 1 The northern dimension structure.

focusing on physical development and avoiding overt political conditionality. In this it resembles other, even more specialized EU instruments for High Northern regional funding. ${ }^{45}$

The ND also puts considerable emphasis on cooperation with the other Regional Councils including BEAC, ${ }^{46}$ and the Northern Dimension Institute in 2012 published a study suggesting some kind of amalgamation between these groups for project-financing and priority setting purposes ${ }^{47}$ This may

45 As mentioned in $\mathrm{n} .3^{2}$ above.

46 E.g., the Arctic Council (AC), the Barents Euro-Arctic Council (BEAC), the Council of the Baltic Sea States (CBSs) and the Nordic Council of Ministers (NCM).

47 A Coherent Northern Dimension, text at <http://www.ndinstitute.org/images/documents/ coherent\%2ond_final.pdf> accessed 19July 2016 . 
be a bridge too far, but all ND participants have committed themselves to 'enhance regional cooperation, improving synergies of regional organization in Northern Europe while avoiding possible duplication'.48 Pace some issues discussed at the end of this section, reinforcing the ND's centrality should offer the most direct way to strengthen the EU's steering position and hence, the chances of mainstreaming its own priorities into the Councils' work.

As its name suggests, the Northern Dimension's geographical coverage extends over the whole northern fringe of Europe from the European Arctic and sub-Arctic areas to the southern parts of the Baltic Sea, and from NorthWest Russia in the East to Iceland and Greenland in the West. However, the scale of ND activities within this region differs substantially, with the bulk of programmes and projects hitherto taking place - in order of magnitude-in the Baltic Sea area, and then in North-west Russia, the Barents region and the Arctic region respectively.

The four ND partners are formally equal, but it is the strategic EU-Russia relationship that sets the pace regarding cooperation in the Baltic Sea region and North-west Russia. There, the Northern Dimension is designed to serve the broader cause of partnership, as seen in the way that ND policies and project prioritization mirror those defined in the 'EU-Russia Common spaces' ${ }^{\prime 9}$ At the level of project design, the EU has consistently mainstreamed its global priorities into the ND agenda: thus in environmental terms, the EU prioritizes protection measures including water and wastewater treatment, waste management and nuclear safety, and works for energy efficiency in support of the EU strategy for the Baltic Sea region. In the field of transport and logistics, the NDPLT fosters the EU's infrastructure priorities and supports measures in line with the revised TEN-T priorities ${ }^{50}$ that are to develop interconnections and eliminate bottlenecks to mobility, complete cross-border routes, cross natural barriers and improve interoperability. ${ }^{51}$

48 This is one of the stated objectives of the Northern Dimension Policy Framework Document, see $n .39$ above.

49 <http://eeas.europa.eu/russia/about/index_en.htm> accessed 19 July 2016.

5o The priorities are to 1) establish and develop key links and interconnections to eliminate existing bottlenecks to mobility, 2) to fill missing sections and complete the main routes especially their cross-border sections, 3) cross natural barriers and 4) improve interoperability on major routes. The overall objective is to stimulate sustainable economic growth at regional level by increased cohesion, interconnection and interoperability of a trans-European transport network, or in the case of NDPLT by focusing priority projects mutually beneficial for EU countries and the non-EU countries in the region.

$5^{1}$ European Commission, Programming of the European Neighbourhood Instrument (ENI) -2014-2020 Regional East Strategy Paper (2014-2020) and Multiannual 
While the ND's cooperative activities in the Baltic Sea and North West Russia are well established and documented, its extension to the Arctic is a work in progress and still somewhat hard to characterize. In principle, the ND's project-based character should allow it to help, like BEAC, in channeling and targeting the EU's existing contributions in the High North, which include a sizeable Arctic research programme ${ }^{52}$ and the above-mentioned regional development funds for specific sub-areas. ${ }^{53}$ The initial description of the ND's Arctic-related role as an 'Arctic window', however, disturbed the Russians who insisted on limiting the programme to the Euro-Arctic zone, not wishing the ND to become a back door into pan-Arctic governance. More recently, Iceland and Norway have called for 'developing the Northern Dimension's contribution to cooperation in the European Arctic area ... deepening and systematizing cooperation between the ND and BEAC, as well as seeking synergies with other relevant cooperation formats and programmes in the Euro-Arctic region.' Concrete proposals in this regard were expected to be presented to an ND Ministerial scheduled for 2015 in Iceland (but see below), while the EU and Russia agreed to develop ideas for the Baltic segment.

For the present, the practical role of the ND in the High North varies from partnership to partnership. The NDEP has a broad remit with regard to promoting environmental protection in various parts of the region. The partnership includes a specific 'nuclear window' through which the partnership contributes to nuclear safety, cross-border impacts and environmental protection in the Arctic (Kola peninsula, Archangelsk and Murmansk regions). As part of its everyday work the NDEP supports projects that support municipal infrastructure modernisation in Northern Russia and Belarus (waste water treatment and district heating modernisation) with the aim of tackling pollution (nutrient input to the sea, $\mathrm{CO}_{2}$ emissions and black carbon emissions). ${ }^{54}$ The ND Partnership on Transport and Logistics (NDPTL) $)^{55}$ has a mandate to facilitate improvement of transport links and logistics-supporting international trade and people-to-people contacts—in the whole ND area, including

Indicative Programme (2014-2017). (2014) <https://eeas.europa.eu/enp/pdf/financing-the -enp/regional_east_strategy_paper_2014_2020_and_multiannual_indicative_programme_ 2014_2017_en_.pdf> accessed 19 July 2016.

European Commission, Report:Arctic Research Funded by the European Union (European Commission 2014) <http://ec.europa.eu/research/bioeconomy/pdf/arctic_research_funded_ by_the_research_and_innovation_eu_en.pdf> accessed 19 July 2016. See $n .32$ above.

$54<$ http://ndep.org/projects/> accessed 19 July 2016.

$55<$ http://www.ndptl.org/home> accessed on 19 July 2016. 
the European Arctic and Barents regions. Providing the only current forum for transport ministries in the Baltic Sea and Barents/Euro-Arctic regions to meet and plan together, it holds much potential for connecting these areas and linking them to global developments in transport and logistics. The remaining two ND partnerships have covered High North issues in a more generalized way, one exception being an NDPHS working group on indigenous health which was however discontinued when Canada left the partnership. In all these fields the ND structures maintain good contact with BEAC counterparts.

Despite the many similarities between the Northern Dimension and the other inclusive Councils of the region-the BEAC, AC and СвSs-its linkages, both political and practical, with the direct EU-Russia relationship are unique and raise special issues. When West-Russia relations are troubled, the ND offers the EU — and its member states - a kind of 'back door' for positive cooperation and the exchange of messages. ${ }^{56}$ In terms of strategy and political sensitivity, this role of the organization arguably outweighs its potential as an extra entry point into Arctic governance, where it is anyway ill-suited to channel issues of high policy. The question is whether the $\mathrm{EU}$ (as a whole) is willing and able to behave accordingly, and whether Moscow can be counted on to comply.

At the time of writing, despite Russian anger over and counter-measures against the EU's Ukraine-related sanctions, ${ }^{57}$ Russia's tactics in all the regional groups seem to be to compartmentalize that issue and continue low-key cooperation as normal. ${ }^{58}$ It is the EU side that has needed to think twice, given the range of feelings among such members as the Baltic States-who are present in the ND (unlike in the BEAC) with veto rights, and who have faced more serious Russian threats and provocations since 2014 than most nations of the Northern flank. Not only had the regular ND Ministerial planned for 2015 been

$5^{6}$ Utilizing meetings within regional constructs for the exchange of messages and to have special bilateral meetings is common practice especially during high level meetings. This is based on the author's (Kristmundur Pór Ólafsson) own observations as an employee of CBSs in Stockholm 2010.

57 European Parliament Briefing: Economic impact on the EU of sanctions over Ukraine conflict, (European Parliament, 2015). <http://www.europarl.europa.eu/RegData/etudes/ BRIE/2015/569020/EPRS_BRI(2015)569020_EN.pdf> accessed 19 July 2016.

$5^{8}$ The most striking success for this tactic was the positive outcome of the Arctic Council meeting at Iqaluit in April 2015 (n. 1 above), followed by an ad hoc meeting in Washington that brought together the us and Russian Foreign Ministers. 
postponed, ${ }^{59}$ but the EU's economic sanctions ${ }^{60}$ have been interpreted in such a way as to block EU-sourced financing for new ND-related projects. ${ }^{61}$ Care has been taken to avoid damage to purely humanitarian and shared causes such as public health; but whether transient or not, this situation prompts the question whether an institution combining membership of all $\mathrm{EU}$ states with a local focus can durably match the success of the smaller High Northern groups (so far) in de-politicization and crisis avoidance. While it delays any stronger ND entry into Arctic affairs, it might also raise doubts over how that development might affect the apparent political stability of other organizations working there.

\section{The West Nordic Council and Its Member}

The West Nordic Council (WNC) started as a purely inter-parliamentary grouping by bringing together delegations from the parliaments of Iceland and the self-governing nations of Greenland and the Faroe Islands. The Council now has a one-person secretariat based in Reykjavík and, impelled largely by Arctic developments, ministers and officials from the three member territories have in the last couple of years also started meeting systematically to discuss West

59 By contrast, a meeting of the ND's Public Health and Social Well-being partnership 'at Ministerial level' took place in November 2015 in Berlin, see the NDPHS website at $<$ http:// www.ndphs.org/?mtgs, pac_11_berlin> accessed on 19 July 2016. States can of course opt to send a lower-level delegate. A meeting of the ND Parliamentary Forum has already taken place as planned at Reykjavik on 10-11 May 2015, where all participants (including Baltic parliamentarians) agreed on 'encouraging all the Partners to continue regional cooperation enhancing mutual understanding in the interest of the peaceful and sustainable development of the ND region'. See $<$ http://www.ndptl.org/c/document_library/ get_file?folderId=10722\&name=DLFE-2409.pdf $>$ accessed 19 July 2016.

6o The reference is to the EU's Ukraine-related measures progressively adopted since March $2014<$ http://europa.eu/newsroom/highlights/special-coverage/eu_sanctions/index_ en.htm\# $5>$ accessed 19 July 2016. They include suspension of ЕІв and EBRD funding for regional cooperative projects, though it is stated that 'projects dealing exclusively with cross-border cooperation and civil society will be maintained'.

61 In the ND context this has been interpreted to preclude funding for any activity discussed/ agreed later than 16 July 2014, and it has serious implications for future action under the four ND partnerships many of whose projects are EIB- or EBRD-dependent. It remains to be seen whether Russia might counter-withdraw its own funding which stands at some $€ 60$ million for the NDEP alone. There are obvious implications also for the CBss, where high-level meetings appear to have been suspended since early 2014. 
Nordic cooperation, with a current focus on building a common trade area. ${ }^{62}$ The WNC has been increasing its ambitions in international relations and has a pending application for observer status of the Arctic Council. ${ }^{63}$ What sets the WNC apart from the other regional formats discussed above is that none of its member is an EU member state while all of the partners have a close association with the EU.

Developments in the Arctic have increased the importance of North-West Atlantic and brought new challenges, responsibilities, opportunities and interest from the world's leading powers. The willingness of the WNC countries to have a say in shaping the future of the Arctic coordination has led to an increased international scope for the Council which could provide a useful fora in which the WNC countries could share experience, expertise and information on issues of regional concern strengthening their position in consultations with leading nations and the $\mathrm{EU}$.

There is no formal link between the EU and the WNC and EU policies and programmes therefore are not directly influencing the decision making of the WNC, but, along with important bilateral cooperation agreements between the EU and the members of the WNC, help form the background against which those decisions are taken. The recently published EU Arctic Strategy ${ }^{64}$ does not mention the WNC specifically as a multilateral fora with Arctic relevance like the BEAC and ND, but rather mentions Greenland and the EEA countries as important partners where the EU can play an influential role in the application of EU rules relevant for the Arctic through the EEA. This is not surprising in light of the limited capacities and scope of the Council hitherto. It is however possible that the WNC could be a platform where the EU could try to engage more actively and consult with the WNC countries on matters relevant to the region in order to mobilize local actors to contribute to EU objectives in the area of climate change and sustainable development. The EU's role as a major contributor to Arctic research and the association of West Nordic states to European funding programmes is an example of this EU angle where joint research projects especially relating to issues like environmental sustainability

62 There is already a free trade agreement (Hoyvik Agreement) between Iceland and the Faroes although this has thrown up some problems. For a general introduction to West Nordic cooperation see Egill Pór Nielsson, 'The West Nordic Council in the Global Arctic, Centre of Arctic Policy Studies (Reykjavik, 2014) <http://ams.hi.is/wp-content/uploads/ 2014/03/the_west_nordic_council.pdf > accessed on 19 July 2016.

63 <http://arcticportal.org/library/news/1294-west-nordic-council-annual-meeting > accessed on 24 July 2016.

$64 \operatorname{JOIN}(2016) 21$. 
and climate change, create a basis for discussion and reactions to Arctic developments. Each WNC member nation is increasingly engaged with the EU on issues fully relevant to the Arctic and that has also been the case with the WNC council itself.

Each year the WNC holds an Annual General meeting which is the Council's supreme authority and which in turn is usually followed by a themed conference, devoted to studying issues of joint concern in more detail. ${ }^{65}$ Recent thematic topics have included the management of natural resources, the question of food safety, and the idea of creating a common Arctic strategy. ${ }^{66}$ This last effort is now mandated to go ahead and will draw upon strategies already adopted by the Icelandic and Faroese parliaments. ${ }^{67} \mathrm{~A}$ joint West Nordic approach to Arctic cooperation can be rationally given, on the one hand, the small size of the three players and their separateness, politically as well as geographically, from the mainstream of European integration. On the other they all have similar aims in Arctic affairs that combine interests in drawing profit from new economic development in the Arctic (shipping, fisheries, and possible oil/gas finds in their waters), and concern over the disruptive environmental changes and the growing risks of major civil emergencies in the region.

The relationship of the EU with the Faroes and Greenland ${ }^{68}$ are quite particular as the Faroes voted to opt out when Denmark joined the EU in $1973,{ }^{69}$ and Greenland followed suit right after it gained Home Rule and withdrew from the Community in $1985 .{ }^{70}$ Today the EU maintains a strong relationship

65 <http://www.europarl.europa.eu/meetdocs/2009_2014/documents/deea/dv/0503_/0503_11 .pdf > accessed 19 July 2016.

66 <http://www.vestnordisk.is/vestnordisk-rad-holder-temakonference-i-grindavik/> accessed on 25 July 2016.

67 See the texts at, respectively, <http://www.mfa.is/media/nordurlandaskrifstofa/AParliamentary-Resolution-on-ICE-Arctic-Policy-approved-by-Althingi.pdf> accessed 19 July 2016, and <http://www.government.fo/foreign-relations/the-faroe-islands-and-the-arctic/> accessed 19 July 2016.

68 Today it belongs to the EU's Overseas Countries and Territories (Ост) scheme. <http:// ec.europa.eu/europeaid/countries/greenland_en>accessed 19 July 2016.

69 For further information see: <http://www.government.fo/foreign-relations/missions-of -the-faroe-islands-abroad/the-mission-of-the-faroes-to-the-european-union/the-faroe -islands-and-the-european-union/> accessed 19 July 2016.

70 A Treaty on Greenland's withdrawal from the Community was made-the Greenland Treaty, <http://naalakkersuisut.gl/en/Naalakkersuisut/Greenland-Representation-to-the -EU/European-Union-and-Greenland/The-Greenland-Treaty-of-1985>accessed 19July 2016. 
with the Faroes ${ }^{71}$ through bilateral agreements while with Greenland the basis for relations is the Greenland Treaty of $1985 .{ }^{72}$ Iceland being a member of the European Economic Area (EEA) and the Shengen treaty it remains outside the EU. Iceland did apply for EU membership and made fast progress in negotiations; but a more traditional centre-right government taking over in 2013 has effectively reversed that step.

Through these relatations the footprint of EU regulation and the influence of EU polices reach far northwards in the Arctic as they provide an opportunity for the EU to have a strong influence on the economic, social and environmental policies in the Arctic. As a major trading partner and consumer of pruducts coming from Arctic it is only natural to assume that the emphasis put on sustainable development, climate change and safeguarding of the Arctic environment in the new EU Arctic policy translate into how the EU conducts itself in its relations to all of those countries. The new Arctic strategy mentions the new EU-Greenland Partnership agreement since 2014 and that 'The EU will further engage in policy dialogue at the appropriate political and technical levels on issues of common concern, such as global issues (energy, climate change and the environment, and natural resources $)^{73}$ and Arctic issues.and furthermore adds that, Arctic policy and Arctic issues will continue to remain an important element of the Eu's close relations with Iceland and Norway' Their new approach to Greenland extends the room for direct dialogue with the homerule government without running into Danish objections. The presentation of EU Arctic policy as such has become steadily more nuanced, to the point where Icelandic specialists acknowledge it as almost identical with their own approach - and thus, potentially, with the concerted goals to be adopted by the three West Nordic players. As a result, Arctic issues not only offer a lifeline for maintaining positive Iceland/EU relations after the halt of accession talks, but could even inject new substance into that relationship, independent

71 See n. 69 above. The Faroes have a bilateral fisheries agreement and a free trade agreement with the EU (as well as similar agreements with Norway and Switzerland) and since 1998 they have maintained an office in Brussels to work directly with the EU institutions.

72 See $n .70$ above.

73 This is a particularly sensitive issue in Greenland given current proposals for new mineral mining, where China has been an interested partner and where observers (i.a. in Denmark) have voiced concern about the environmental and social consequences. One of the schemes would, moreover, involve extracting uranium ore as a by-product: see Cindy Westergaard, 'The European Union, its Overseas Territories and Non-Proliferation: The case of Arctic yellowcake', SIPRI Non-Proliferation Papers no. 25. 2013, at <http:// www.nonproliferation.eu/web/documents/nonproliferationpapers/cindyvestergaard 5of 42 aag586fe.pdf > accessed 19 July 2016. 
of what happens over the EU's AC observership (which, incidentally, Iceland supports).

Is there a case for the $\mathrm{EU}$ also to seek institutional relations with the WNC itself? It is certainly in the broader European interest to encourage rational cooperation among the three small and vulnerable nations involved, and to make sure that their emergent joint policies take account of relevant EU positions and instruments. However, there are also arguments against haste. The WNC is the smallest and institutionally weakest of the North's sub-regional groups, already facing other demands for association and partnership that risk over-burdening it. The most effective outlet for WNC proposals is through the larger Nordic Council ${ }^{74}$ and it would be wrong to distract attention and resources from that channel. Moreover, the tolerance of West Nordic élites for an EU role-not only as a milch-cow, but in the interests of wider Arctic balance and governance-does not necessarily extend to their less well informed and more suspicious publics. The best near-term approach could be for the EU to keep itself informed on West Nordic developments, and inject ideas as appropriate, through its bilateral diplomacy with Iceland and Greenland in particular.

5

Summary and Conclusions

The contributions of sub-regional bodies to Arctic affairs is shaped by their own strengths and weaknesses. The strategic value and functionality of these structures offers the EU venues to work with and through to have an influential role in shaping the future developments of the European part of the Arctic by the promotion of its policies and financial instruments. The 'weak' features of bodies like the BEAC and ND gives them opportunity to operate in de-securitized and almost de-politicized mode even amidst serious strategic tensions.

The regional structures have provided a common platform where State and non-State actors have been able to find common position and solutions on the great challenges being faced in the Arctic region and their loose governance methods threaten neither sovereignty, nor distinct State and ethnic identities; and the money they draw in and/or redistribute is welcome to all. Anything that they do for stability, understanding, and non-military cooperation among

74 While not discussed in this paper, the Nordic group's institutional engagement with and influence in Arctic affairs is considerable and growing: see Bailes and Ólafsson, n. 26 above. 
Arctic neighbours is in the broad interests of the EU, as a 'soft-power' actor that relies on its regulatory strength, funds, and image rather than military might. ${ }^{75}$ Anything the groups can do for economic, social and functional development in Arctic land areas expands the chances of profitable trade and cooperation for the rest of Europe, both with and through these zones. It may even be argued that the successes of 'soft' or 'weak' institutionalization in the European segment of the Arctic have made European models and influences more effective across the whole circumpolar space than the prima facie clout of the small Nordic nations might suggest. ${ }^{76}$ Last and not least, should Greenland and/ or the Faroes gain full independence at any time, the sub-regional networks would offer them a 'home to go to' for support, guidance and restraint, even if they continued to reject more direct $\mathrm{EU}$ links. ${ }^{77}$

Pace many Arctic analysts, moreover, the groups' cumulative limitations are only damaging for the Arctic's chances of stability and sustainable development if the gaps they leave are not or cannot be filled by others. In fact, some key Arctic challenges are covered by global instruments like the UN Convention on the Law of the Sea, ${ }^{78}$ the military balance is looked after (for good or ill) by the Russia-NATO relationship; ${ }^{79}$ and as this paper has tried to show, the EU itself influences economic, social and functional development in far more ways than most analyses give credit for.

From published facts and the testimony of officials interviewed for this project, it is clear that these realities are not lost on officials in Brussels. The

75 Bretherton, Charlotte and John Vogler. The European Union as a Global Actor (2nd Edn, Routledge, 2006).

76 There are no comparable inter-governmental groups in the Pacific segment. For more on this see Bailes, see n. 3 above.

77 A further point might be made that strengthening a European common front in the Arctic could help offset growing Chinese (and other Asian) efforts to play a role there. However, it is Russia that in reality has most reason for concern about infiltration and competition from a rising China, and the small European Arctic nations have welcomed rather than resisted Chinese overtures. See Marc Lanteigne, 'China's Emerging Arctic Strategies: Economics and Institutions' Centre forArctic Policy Studies, Occational paper (Reykjavík, 2014) <http://ams.hi.is/wp-content/uploads/2014/11/Marc_Lanteigne2.pdf> accessed 22 July 2016.

78 United Nations Convention on the Law of the Sea (adopted 10 December 1982, entered into force 16 November 199431363 UNTS 1833, 1834, 1835 .

79 For more on this argument see Alyson J.K. Bailes, 'Institutions and Stability in Lassi Heininen and Regis Rouge-Oikarinen (eds), The Arctic Case' in NGP Yearbook 2011: Sustainable development in the Arctic region through peace and stability, (Nordia Geographical Publications, 2012) 43-56. 
strategic vision and practical coordination of EU Arctic policies has been steadily improving since 2008, with the fact that the Commission's 2012 report was co-authored by the High Representative ${ }^{80}$ was one milestone. The recently published EU policy for the Arctic is also co-authored by the High Representative recognized the value of regional cooperation fora, not only for the value of sharing experience, expertise and information but as partners to be included in developing an ambitious climate adaption agenda for the Arctic region. The policy mentions the importance of relations with the EEA countries and Greenland and gives honourable mention to the BEAC and ND policy frameworks as successful cooperation frameworks. The policy does however emphasize the need to enhance the collaboration and coordination between different EU funding programmes as well as bring together the EU institutions, Member States and regional and local authorities in order to help identify investment and research priorities in the region. Behind such words lie concrete EU interests and ambitions to place a European mark on Arctic developments (at least in the Euro-Atlantic zone); to promote generic EU policies where applicable; to use neighbourhood cooperation funds in a more targeted, coherent and productive way; and to its deepen relations with both state and non-state players active in the region.

By and large, the EU's approach in recent years has registered steady improvements on all these fronts. It will remain important for Brussels to avoid an over-assertive Besserwisser ('one who knows better') approach, and to accept more indirect ways of spreading European ideas on occasionnotably through the Nordics, and perhaps also through private sector actors and NGOS. The Russian side is currently more sensitive than ever to European/ Western 'ganging up', and it remains to be seen whether the Northern Dimension in particular can avoid lasting damage from some EU members' insistence on extending sanctions to the financing of its collectively sponsored projects. The de-politicization and humble profile that allow sub-regional cooperation to make its most characteristic contributions may, it seems, be among the hardest characteristics for EU politicians to absorb and emulate. That could raise questions in some minds about how the EU would use any stronger status it may eventually gain in the Arctic Council. The answer matters, because a peaceful Arctic is ultimately in the interest of all Europeans.

8o European Parliament and European Council, Communication on Developing a European Union Policy towards the Arctic Region: progress since 2008 and next steps, JOIN(2012) 19, 26 June 2012. <http://eeas.europa.eu/arctic_region/docs/join_2012_19.pdf> accessed 19 July 2016. 